\title{
Effects of a fentanyl-propofol mixture on propofol injection pain: a randomized clinical trial
}

\author{
Nurcan Kizilcik, Ferdi Menda, Sevgi Bilgen, Ozgül Keskin, and Ozge Koner \\ Department of Anesthesiology and Reanimation, Yeditepe University School of Medicine, Istanbul, Turkey
}

Background: Propofol injection pain is a common problem that can be very distressing for patients. We compared the effects of injection with saline followed by injection with a fentanyl-propofol mixture, injection with fentanyl followed by a propofol injection, and injection with saline followed by propofol alone on propofol injection pain.

Methods: The patients were assigned randomly to one of three groups. A rubber tourniquet was placed on the forearm to produce venous occlusion for $1 \mathrm{~min}$. Before anesthesia induction, group $\mathrm{C}$ (control, $\mathrm{n}=50$ ) and group $\mathrm{M}$ (fentanylpropofol mixture, $\mathrm{n}=50$ ) received $5 \mathrm{ml}$ of isotonic saline, while group $\mathrm{F}$ (fentanyl, $\mathrm{n}=50$ ) received $2 \mu \mathrm{g} / \mathrm{kg}$ of fentanyl. After the tourniquet was released, groups $\mathrm{C}$ and $\mathrm{F}$ received $5 \mathrm{ml}$ of propofol and group $\mathrm{M}$ received $5 \mathrm{ml}$ of a mixture containing $20 \mathrm{ml}$ of propofol and $4 \mathrm{ml}$ of fentanyl. At $10 \mathrm{~s}$ after the study drugs were given, a standard question about the comfort of the injection was asked of the patient. We used a verbal rating scale to evaluate propofol injection pain. Statistical analyses were performed with Student's t-tests and Fisher's exact tests; $\mathrm{P}<0.05$ was considered to indicate statistical significance.

Results: The demographic data were similar among the groups. In group $\mathrm{M}$, the number of patients reporting propofol injection pain was significantly lower than in groups $\mathrm{F}$ and $\mathrm{C}$ (both $\mathrm{P}<0.001$ ). No patient in group $\mathrm{F}$ or $\mathrm{M}$ experienced severe pain, whereas 24 patients $(48 \%)$ had severe pain in group C (both $\mathrm{P}<0.001)$.

Conclusions: This study shows that a fentanyl-propofol mixture was more effective than fentanyl pretreatment or a placebo in preventing propofol injection pain.

Key Words: Fentanyl, Injection pain, Propofol.

\section{Introduction}

Propofol has gained wide acceptance among anesthesiologists due to its favorable induction characteristics, including its

Corresponding author: Nurcan Kizilcik, M.D.

Department of Anesthesiology, Yeditepe University School of Medicine,

Devlet yolu Ankara Cad. No:102-104 Kozyatag1, İstanbul 34752, Turkey

Tel: 90-216-5784761, Fax: 90-216-4693796

E-mail: nurcankizilcik@gmail.com

Received: November 19, 2014.

Revised: March 16, 2015.

Accepted: April 3, 2015.

Korean J Anesthesiol 2015 December 68(6): 556-560

http://dx.doi.org/10.4097/kjae.2015.68.6.556 rapid onset time and fast elimination half-life. However, intravenous (i.v.) propofol injections are painful, making the induction of anesthesia uncomfortable for the patient and anesthesiologist [1-4].

Several pharmacological interventions have been described to reduce or prevent propofol injection pain [3], including cooling or diluting the propofol solution, or applying propofol in tandem with local anesthetics, ondansetron, ketamine, magnesium sulfate, non-steroidal anti-inflammatory drugs, or opioids [5-12].

Fentanyl given just before propofol diminishes propofol injection pain, but it is unclear whether fentanyl has this effect when used in a mixture with propofol [4]. We compared the effects of injection with saline followed by injection with a fentanyl-propofol mixture, injection with fentanyl followed by

(c) This is an open-access article distributed under the terms of the Creative Commons Attribution Non-Commercial License (http://creativecommons.org/ licenses/by-nc/4.0/), which permits unrestricted non-commercial use, distribution, and reproduction in any medium, provided the original work is properly cited. 
a propofol injection, and injection with saline followed by propofol alone on propofol injection pain. We hypothesized that a fentanyl-propofol mixture might reduce the pain related to propofol injection more effectively than fentanyl pretreatment alone.

\section{Materials and Methods}

This study was conducted with Institutional Review Board approval and was registered with the www.clinicaltrials.gov protocol registration system (NCT02203175). Ethical approval (No. 100: 25/05/2011) was provided by the Ethics Committee of Yeditepe University Hospital, Istanbul, Turkey (Chairperson: Dr. Kemal Saricali), on May 25, 2011. Informed consent was obtained from each patient.

Study data were collected at Yeditepe University Hospital from April 2011 to April 2012. In total, 150 American Society of Anesthesiologists physical status I-II patients, aged 18-65 years old, who were scheduled for elective surgery were enrolled. The exclusion criteria were communication difficulties, psychiatric and neurological disorders, history of allergy to the study drugs, and use of analgesics or sedative drugs within $24 \mathrm{~h}$ before surgery.

The study was designed in a prospective, randomized, and double-blind fashion. Patients were assigned randomly to one of three groups using an Excel (Microsoft, Redmond, WA, USA)generated randomization table. No patient received premedication. Before the induction of anesthesia, it was explained to the patients that they would be receiving i.v. anesthetics that might cause pain in the forearm. On arrival at the operating room after monitoring (ECG, non-invasive blood pressure, pulse oximeter, and bispectral index [BIS]), a 20-gauge cannula was inserted into a vein on the dorsum of the patient's non-dominant hand and a $0.9 \% \mathrm{NaCl}$ infusion was started at $5 \mathrm{ml} / \mathrm{kg} / \mathrm{h}$ for $5 \mathrm{~min}$.

Next, the i.v. infusion was stopped and the arm with the i.v. line was elevated for $15 \mathrm{~s}$ to facilitate gravity drainage of venous blood. A rubber tourniquet was placed on the forearm to produce venous occlusion for $1 \mathrm{~min}$. The anesthesiologist who pretreated the patients was blinded to each patient's allocation. Before anesthesia induction, the subjects in groups $\mathrm{C}$ (control, $\mathrm{n}=50$ ) and $\mathrm{M}$ (mixture, $\mathrm{n}=50$ ) received $5 \mathrm{ml}$ of isotonic saline, whereas those in group $\mathrm{F}$ (fentanyl, $\mathrm{n}=50$ ) received $2 \mu \mathrm{g} / \mathrm{kg}$ of fentanyl diluted with saline to a total volume of $5 \mathrm{ml}$ as a pretreatment (1\% propofol [Fresenius Kabi, Bad Homburg, Germany]; $0.05 \mathrm{mg} / \mathrm{ml}$ fentanyl [Janssen-Cilag Pty. Ltd., Macquarie Park, Australia]) at an injection rate of $0.5 \mathrm{ml} / \mathrm{s}$.

The drugs were prepared by one of the investigators, who was blinded to the study groups. The pretreatment solutions were identical in appearance. All study drugs were prepared preoperatively at room temperature. The $\mathrm{pH}$ values of the fen- tanyl, propofol, and fentanyl-propofol solutions were measured with a pH meter (InoLab 740 with terminal 740; WTW GmbH, Weilheim in Oberbayern, Germany). For the patients in group $\mathrm{M}$, the mixture of fentanyl and propofol was prepared using 20 $\mathrm{ml}$ of propofol and $4 \mathrm{ml}$ of fentanyl. After the tourniquet was released, the patients in groups $\mathrm{C}$ and $\mathrm{F}$ received $5 \mathrm{ml}$ of propofol whereas the patients in group $\mathrm{M}$ received $5 \mathrm{ml}$ of the fentanylpropofol mixture at an injection speed of $0.5 \mathrm{ml} / \mathrm{s}$.

At $10 \mathrm{~s}$ after the study drugs had been given, a standard question about the comfort of the injection was asked of the patient. We used a verbal rating scale (VRS) to evaluate the severity of pain due to the injection of propofol [5,10-12]: 0 , none (negative response to questioning); 1 , mild pain (pain reported only in response to questioning without any behavioral signs); 2 , moderate pain (pain reported in response to questioning and accompanied by behavioral signs or pain reported spontaneously without questioning); or 3, severe pain (strong vocal response or response accompanied by facial grimacing, arm withdrawal, or tears). All patients were able to answer the question; additionally, in all patients the BIS was above 80 at the time of questioning.

The remaining dose of propofol and fentanyl was then given to complete the induction of anesthesia. The complete induction dose was $2 \mathrm{mg} / \mathrm{kg}$ of propofol and $2 \mu \mathrm{g} / \mathrm{kg}$ of fentanyl. All patients were given $0.5 \mathrm{mg} / \mathrm{kg}$ of atracurium for muscle relaxation. Because groups $\mathrm{F}$ and $\mathrm{M}$ had already received $2 \mu \mathrm{g} / \mathrm{kg}$ of fentan$\mathrm{yl}$, only the patients in group C received $2 \mu \mathrm{g} / \mathrm{kg}$ of fentanyl after the muscle relaxant. After orotracheal intubation, anesthesia was maintained with $1.0-2.0 \%$ sevoflurane and $60 \%$ nitrous oxide in oxygen with controlled mechanical ventilation.

The primary outcome was a complete response (no injection pain, VRS $=0$ ). The secondary outcome was propofol injection pain.

\section{Statistical analysis}

Propofol injection pain was the primary outcome. The reported incidence of propofol injection pain is $\sim 70 \%$; to decrease this incidence to $35 \%$, it was calculated that 49 patients would be needed in each group with a type I error of 0.05 and power of $90 \%$. Due to possible subject drop-out, 50 patients per group were entered into the study.

Demographic data were compared using Student's t-test. Fisher's exact test and $\chi^{2}$ tests were used to assess differences between categorical variables. $\mathrm{P}<0.05$ was considered to indicate statistical significance.

\section{Results}

In total, 150 patients were studied. Fig. 1 shows a flow chart of the study, and Table 1 shows the demographic data for the pa- 


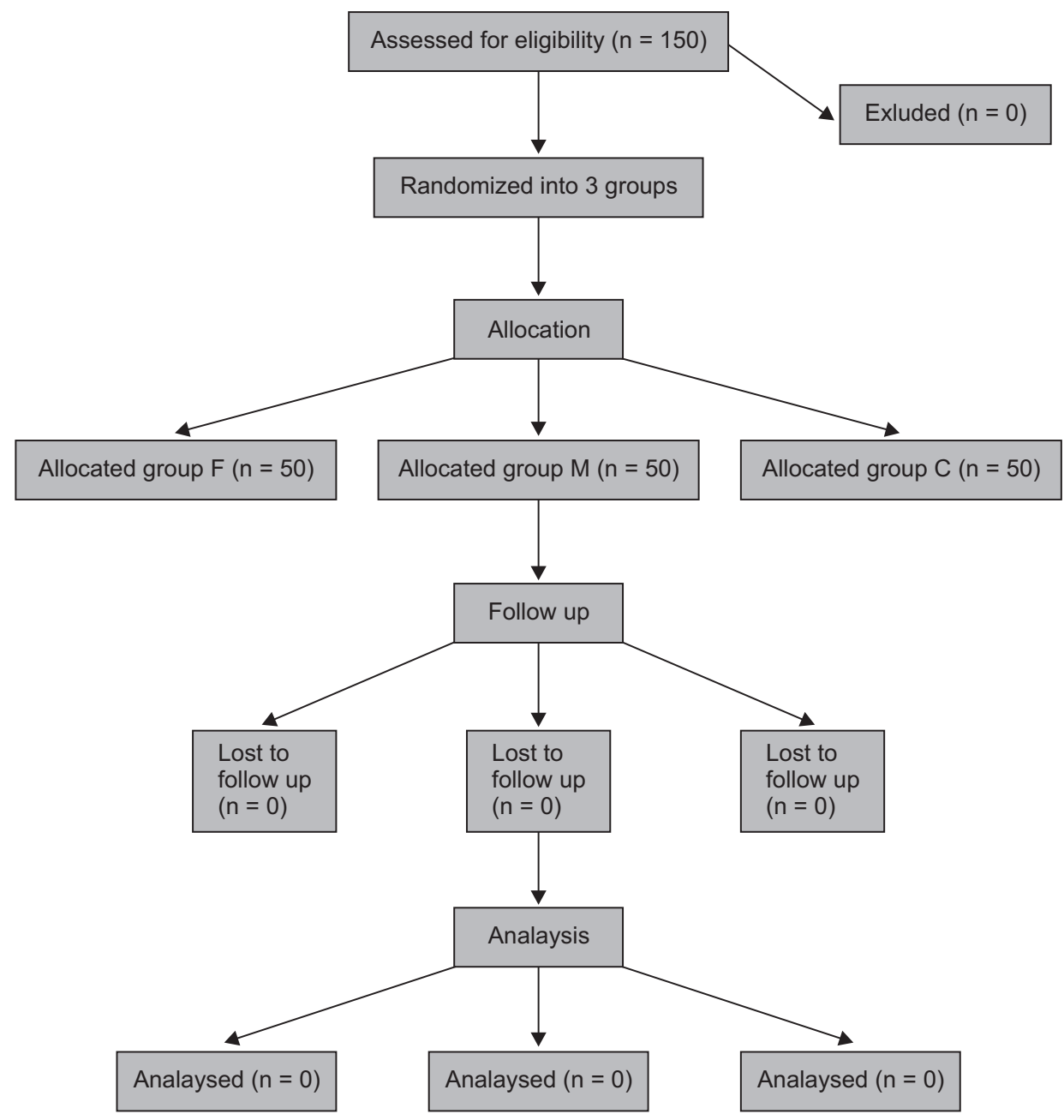

Fig. 1. Showing randomized into 3 groups flow chart.

Table 1. Demographic Data

\begin{tabular}{lccc}
\hline & $\begin{array}{c}\text { Group M } \\
(\mathrm{n}=50)\end{array}$ & $\begin{array}{c}\text { Group F } \\
(\mathrm{n}=50)\end{array}$ & $\begin{array}{c}\text { Group C } \\
(\mathrm{n}=50)\end{array}$ \\
\hline Age (yr) & $42 \pm 13$ & $44 \pm 11$ & $43 \pm 9$ \\
Gender (M/F) & $26 / 24$ & $27 / 23$ & $23 / 27$ \\
Weight (kg) & $76 \pm 9$ & $74 \pm 10$ & $77 \pm 8$ \\
\hline
\end{tabular}

tients. There was no significant difference in age, weight, or sex among the three groups. The incidence and severity of propofol injection pain are shown in Table 2 .

In all cases, it was possible to obtain clear answers from the patient before the patient became anesthetized. The overall incidence of propofol injection pain was $100 \%$ (50/50) in group C, $92 \%(46 / 50)$ in group $\mathrm{F}$, and $64 \%(32 / 50)$ in group $\mathrm{M}$. The overall incidence of propofol injection pain in group $\mathrm{F}$ was not different from that in group $\mathrm{C}$, whereas the incidence in group $\mathrm{M}$ was significantly lower than that in group $\mathrm{C}(\mathrm{P}=0.0001)$. Compared with group $\mathrm{F}$, the incidence of propofol pain in group $\mathrm{M}$ was significantly lower $(\mathrm{P}=0.001)$.
Table 2. Severity of Injection Pain

\begin{tabular}{lccc}
\hline Severity of injection pain & $\begin{array}{c}\text { Group F } \\
(\mathrm{n}=50)\end{array}$ & $\begin{array}{c}\text { Group M } \\
(\mathrm{n}=50)\end{array}$ & $\begin{array}{c}\text { Group C } \\
(\mathrm{n}=50)\end{array}$ \\
\hline None (n) & 4 & 18 & 0 \\
Mild (n) & $18^{*}$ & $24^{*}$ & 6 \\
Moderate (n) & 28 & $8^{\dagger}$ & 20 \\
Severe (n) & $0^{+}$ & $0^{+}$ & 24 \\
Number of the patients & 46 & 32 & 50 \\
$\quad$ within injection pain (n) & & & \\
\hline
\end{tabular}

$\overline{\text { *Increase compared to Group C }(\mathrm{P}<0.05) .{ }^{\dagger} \text { Significant decrease }}$ compared to Group C $(\mathrm{P}<0.05)$.

In group C, $48 \%$ of the patients (24/50) experienced severe pain, whereas no patient did in groups $\mathrm{F}$ and $\mathrm{M}$ (significance between group $\mathrm{F}$ and group $\mathrm{M}$ compared with group $\mathrm{C}, \mathrm{P}=0.0001$ and 0.0001 , respectively).

The incidence of patients with moderate pain was significantly lower in group M $(16 \% ; 8 / 50)$ than in group C $(40 \% ; 20 / 50$; P $=0.013)$. There was no difference in the incidence of moderate pain between groups $\mathrm{F}$ and $\mathrm{C}$. 
In both groups $\mathrm{F}$ and $\mathrm{M}$, the incidence of mild pain was significantly higher than in the control group $(\mathrm{P}=0.009$ and 0.0002 , respectively). No difference was found between groups F and $\mathrm{M}$ with respect to mild pain.

The $\mathrm{pH}$ values of the propofol, fentanyl, and fentanyl-propofol solutions were $8.04,4.45$, and 7.42 , respectively.

\section{Discussion}

Our results indicate that the mixture of fentanyl and propofol significantly reduced the incidence and severity of propofol injection pain compared with the control group. In contrast, fentanyl pretreatment did not reduce the incidence or severity of pain compared with the control group.

Although the mechanism underlying propofol injection pain is unclear, many factors affect the incidence of pain, including the site of injection, size of the vein, speed of injection, propofol concentration in the aqueous phase, buffering effect of the blood, speed of intravenous carrier fluid, temperature of the propofol solution, syringe material, and the concomitant use of drugs (e.g., local anesthetics and opioids) [1,2].

Several methods have been described to reduce propofol injection pain, including the use of a larger vein and pretreatment with pharmacological agents such as lidocaine, opioid analgesics, ketamine, meperidine, metoclopramide, diphenhydramine, magnesium sulfate, and non-steroidal anti-inflammatory agents [4-15]. The effects of temperature and dilution as well as varying the infusion rate have also been studied [16-19].

Propofol injection pain can be immediate or delayed. It has been suggested that immediate pain results from a direct irritant effect, whereas delayed pain may be caused by an indirect effect via the kinin cascade [20].

The site of action of opioids in reducing propofol injection pain may be central or peripheral [21]. Opioid receptors on peripheral terminal afferent nerves can mediate potent antinociceptive effects [22].

In this study, we used a tourniquet to isolate the arm veins from the rest of the circulation. This has been suggested to be a useful model for studying the peripheral actions of a drug [23].

The $\mathrm{pH}$ values of the propofol, fentanyl, and fentanyl- propofol solutions were measured in our laboratory $(8.04,4.45$, and 7.42, respectively). Because the $\mathrm{pH}$ value of fentanyl is lower than that of propofol, the $\mathrm{pH}$ value of the propofol-fentanyl mixture was lower than that of propofol alone. Eriksson et al. [24] reported that decreasing the $\mathrm{pH}$ of propofol resulted in a lower concentration of propofol in the aqueous phase.

Klement and Arndt [25] suggested that the concentration of propofol in the aqueous phase was a determining factor in propofol injection pain. In a bolus injection, only the outer aqueous phase comes into contact with the intima of the vein, and venous pain on administration of the irritating agent may be caused primarily by the concentration of the irritating agent in the aqueous phase [26]. Lowering the $\mathrm{pH}$ value of propofol by mixing it with fentanyl may explain the decreased incidence of propofol injection pain. Helmer et al. [26] reported a significant reduction in the incidence of propofol injection pain, from 40 to $16 \%$, with the use of fentanyl before propofol. These incidences are much lower than the ones in our study. In our study, pain incidence was $100 \%$ in the control group and $92 \%$ in the fentanyl pretreatment group. These differences may be due to methodological differences between the two studies. In Helmer's study [26], patients were asked about pain after receiving $1.5 \mathrm{mg} / \mathrm{kg}$ of propofol and the BIS was not monitored. It is possible that after this dose of propofol, the patients were too deeply sedated to answer the question about pain correctly. This may explain why the reported incidence was so low compared with that in our study. Another reason may be the vein and i.v. cannula size (17 vs. $20 \mathrm{G}$ ) used in their study compared with ours, which may influence the incidence of propofol injection pain [27].

When mixing two drugs, major concerns are compatibility and the stability of the mixture. In our study, no precipitation was observed in the syringe. Stewart et al. [27] stated that propofol and fentanyl were compatible and stable when mixed together. The subjective nature of the four-point injection pain evaluation scale is a limitation of our study. Another limitation is that this method cannot be applied without tourniquet use.

In conclusion, fentanyl mixed with propofol reduced injection pain significantly compared with the control and fentanyl pretreatment groups.

\section{References}

1. Jalota L, Kalira V, George E, Shi YY, Hornuss C, Radke O, et al. Prevention of pain on injection of propofol: systematic review and metaanalysis. BMJ 2011; 342: d1110.

2. Tan CH, Onsiong MK. Pain on injection of propofol. Anaesthesia 1998; 53: 468-76.

3. Marik PE. Propofol: therapeutic indication and side-effect. Curr Pharm Des 2004; 10: 3639-49.

4. Picard P, Tramèr MR. Prevention of pain on injection with propofol: a quantitative systematic review. Anesth Analg 2000; 90 : 963-9.

5. McCrirrick A, Hunter S. Pain on injection of propofol: the effect of injectate temperature. Anaesthesia 1990; 45: 443-4. 
6. Stokes DN, Robson N, Hutton P. Effect of diluting propofol on the incidence of pain on injection and venous sequelae. Br J Anaesth 1989; 62: 202-3.

7. Saadawy I, Ertok E, Boker A. Painless injection of propofol: pretreatment with ketamine vs thiopental, meperidine, and lidocaine. Middle East J Anaesthesiol 2007; 19: 631-44.

8. Ambesh SP, Dubey PK, Sinha PK. Ondansetron pretreatment to alleviate pain on propofol injection: a randomized, controlled, doubleblinded study. Anesth Analg 1999; 89: 197-9.

9. Iyilikci L, Balkan BK, Gökel E, Günerli A, Ellidokuz H. The effects of alfentanil or remifentanil pretreatment on propofol injection pain. J Clin Anesth 2004; 16: 499-502.

10. Basaranoglu G, Erden V, Delatioglu H, Saitoglu L. Reduction of pain on injection of propofol using meperidine and remifentanil. Eur J Anaesthesiol 2005; 22: 890-2.

11. Kwak K, Kim J, Park S, Lim D, Kim S, Baek W, et al. Reduction of pain on injection of propofol: combination of pretreatment of remifentanil and premixture of lidocaine with propofol. Eur J Anaesthesiol 2007; 24: 746-50.

12. Apiliogullari S, Keles B, Apiliogullari B, Balasar M, Yilmaz H, Duman A. Comparison of diphenhydramine and lidocaine for prevention of pain after injection of propofol: a double-blind, placebo-controlled, randomized study. Eur J Anaesthesiol 2007; 24: 235-8.

13. Koo SW, Cho JS, Kim YK, Ham KD, Hwang JH. Small-dose ketamine reduces the pain of propofol injection. Anesth Analg 2006; 103: 1444-7.

14. Memiş D, Turan A, Karamanlioğlu B, Süt N, Pamukçu Z. The use of magnesium sulfate to prevent pain on injection of propofol. Anesth Analg 2002; 95: 606-8.

15. Walker BJ, Neal JM, Mulroy MF, Humsi JA, Bittner RC, McDonald SB. Lidocaine pretreatment with tourniquet versus lidocaine-propofol admixture for attenuating propofol injection pain: a randomized controlled trial. Reg Anesth Pain Med 2011: 36: 41-5.

16. Parmar AK, Koay CK. Pain on injection of propofol. A comparison of cold propofol with propofol premixed with lignocaine. Anaesthesia 1998; 53: 79-83.

17. Klement W, Arndt JO. Pain on injection of propofol: effects of concentration and diluent. Br J Anaesth 1991; 67: 281-4.

18. Grauers A, Liljeroth E, Akeson J. Propofol infusion rate does not affect local pain on injection. Acta Anaesthesiol Scand 2002; 46: 361-3.

19. Shimizu T, Inomata S, Kihara S, Toyooka H, Brimacombe JR. Rapid injection reduces pain on injection with propofol. Eur J Anaesthesiol 2005; 22: 394-6.

20. Briggs LP, Clarke RS, Dundee JW, Moore J, Bahar M, Wright PJ. Use of di-isopropyl phenol as main agent for short procedures. Br J Anaesth 1981; 53: 1197-202.

21. James MK, Feldman PL, Schuster SV, Bilotta JM, Brackeen MF, Leighton HJ. Opioid receptor activity of G187087B, a novel ultra-short acting analgesic in isolated tissues. J Pharmacol Exp Ther 1991; 259: 712-8.

22. Rahman Al-Refai A, Al-Mujadi H, Petrova Ivanova M, Marzouk HM, Batra YK, Al-Qattan AR. Prevention of pain on injection of propofol: a comparison of remifentanil with alfentanil in children. Minerva Anesthesiol 2007; 73: 219-23.

23. Borazan H, Erdem TB, Kececioglu M, Otelcioglu S. Prevention of pain on injection of propofol: a comparison of lidocaine with different doses of paracetamol. Eur J Anaesthesiol 2010; 27: 253-7.

24. Eriksson M, Englesson S, Niklasson F, Hartvig P. Effect of lignocaine and pH on propofol induced pain. Br J Anaesth 1997; 78: 502-6.

25. Klement W, Arndt JQ. Pain on injection of propofol: effects of concentration and diluent. Br J Anaesth 1991; 67: 281-4.

26. Helmers JH, Kraaijenhagen RJ, Leeuwen LV, Zuurmond WW. Reduction of pain on injection caused by propofol. Can J Anaesth 1990; 37: 267-8.

27. Stewart JT, Warren FW, Maddox FC, Viswanatan K, Fox JL. The stability of remifentanil hydrochloride and propofol mixtures in polypropylene syringes and polyvinylchloride bags at 22 degrees-24 degrees C. Anesth Analg 2000; 90: 1450-1. 